\title{
Problem-solving skills of futsal players with regard to some socio-demographic variables
}

\author{
Musa CON ${ }^{1}$, Kursat ACAR ${ }^{2}$, Soner CANKAYA3 \\ Mehmet Yalcin TASMEKTEPLIGIL ${ }^{1}$ \\ ${ }^{1}$ Faculty of Sports Sciences, Ondokuz Mayıs University, Samsun, Turkey \\ ${ }^{2}$ Faculty of Sports Sciences, Sinop University, Sinop, Turkey \\ ${ }^{3}$ Faculty of Medicine, Ordu University, Ordu, Turkey \\ Address correspondence to K. Acar, e-mail: kursatacar@sinop.edu.tr
}

\begin{abstract}
The aim of this study is to evaluate problem-solving skills of female futsal teams that compete in the Futsal League of Turkish Universities Sports Federation in terms of some socio-demographic variables. In total, 144 students from female futsal teams of 10 universities competing in the Futsal League of Turkish Universities Sports Federation voluntarily took part in this study. In the study, "Problem-Solving Inventory" that was developed by Heppner \& Petersen was used. With this inventory, such sub-dimensions of the participants as "reliance on problem-solving skill", "approach-avoidance" and "self-control" were analysed. In the statistical analysis of the obtained data during the research study, differences have been revealed by using one-way analysis of variance (One-Way ANOVA). And in the comparison of the averages of groups, Tukey HSD multiple comparison test was used. Research findings revealed that there are statistically significant differences between the points gained from the sub-dimensions of "reliance on problem-solving skill" and "approach-avoidance" with respect to the participants' sporting age and the attended school; "reliance on problem-solving skill" with regard to father's educational background; "approach-avoidance" with respect to income level $(\mathrm{P}<0.05)$. As a result, it is understood that such variables as sporting age, father's educational background, income level and the attended university have important effects on individuals, and it is seen that individual's level of solving problems increases as the sporting age increases. Within this scope, individuals are advised to start doing sports at early ages in order for them to develop their problem-solving skills.
\end{abstract}

Keywords: Futsal, futsal league, problem, problem-solving skills.

\section{INTRODUCTION}

An individual comes across various little or big problems under different circumstances during certain periods of his/her life. And the reactions towards these problems vary from person to person. Many people attempt to solve the same problem by using many different approach styles, and some fail while others succeed (8).

Problem can be generally explained as a challenge to be resolved or a question to be answered (4).

Problem-solving is a cognitive and behavioral process that requires high-level of consideration, and involves the determination of effective problemsolving ways, choosing proper solutions and deciding well (9).
Problem-solving skill helps individuals and groups adapt effectively to their environment. Solving problems need multi-disciplinary knowledge, multiple thinking and creativity (20).

In this sense, problem-solving skill is an inevitable quality that enables individuals to handle the challenges and to succeed. Therefore, problemsolving is one of the most important living skills of individuals. Hence, individual goes on his/her life more smoothly (7). Sport, undoubtedly, takes an important place in an individual's life with relation to other living spaces, and contributes much to their behavioral development. Within this scope, futsal, which developed as a special type of football, is a kind of sports that requires high-level technical and tactical capacity concerning the game and quick deciding. So, it is thought very important that players 
have enough speed and coordination to make the truest choice during the game, and that they can conduct desired skills. In such competences in which game goes on with lightning speed as futsal, this situation becomes more important, and therefore individual skills and differences of the players come into prominence. As a matter of fact, players perform 146 tactical moves in a confined space during football game while this number reaches up to 536 in a futsal game (7). Therefore, duties and responsibilities of the players on the pitch happen faster according to game's needs.

When futsal is viewed from this perspective, it is thought that such problem-solving levels as "reliance on problem-solving skill", "approach-avoidance" and "self-control", which are sub-dimensions of problem-solving skill are important with regard to performance and success.

Within this framework, the aim of this study is to compare problem-solving skills of female futsal teams of the universities by correlating them to some personal variables in sub-dimension categories.

\section{MATERIALS \& METHODS}

\section{Research Model}

This research has the characteristics of screening model, and presents a descriptive quality. Screening models is a research style aiming to describe a situation in the past or still present as it is. The incident, individual or object that are subject of the research are tried to be expressed under their own circumstances and as they are (15).

\section{Participants}

The players who play in the Futsal League of Turkish Universities Sports Federation constitute the population of the study; players of 10 universities in total 144 students that were chosen as cluster sampling within the universities having teams in aforesaid league. These are Afyon Kocatepe University (AKU, n=15), Atatürk University (AU, $\mathrm{n}=12$ ), Dumlupınar University (DU, n=17), Gümüşhane University (GU, n=18), Giresun University (GU, n=11), Karabük University (KU, $\mathrm{n}=10$ ), Karadeniz Technical University(KTU, n=15), Mehmet Akif Ersoy University (MAKU, n=15), Ondokuz Mayıs University (OMU, n=21), Ordu University (ODU, $\mathrm{n}=10$ ) respectively.

\section{Data Collection Tool}

In the study, as data collection tool, "Problemsolving inventory" developed by Heppner and
Petersen (12) was used and adapted into Turkish by Taylan (25), Savaşır \& Şahin (23). Cronbach's Alpha reliability coefficient of thirty-five point inventory that involves positive and negative statements is 0.90 , and items have response options that are suited for six rating grades. Varying points from 1 to 6 are given to the responses in the inventory. While grading the inventory, total point was calculated by reversing the negative statements. Because of inventory protocol $9^{\text {th }}, 22^{\text {nd }}, 2^{\text {th }}$ and $32^{\text {nd }}$ items were left out in evaluation process. Therefore, the lowest point is 31 , and the highest one is 186. High-level of total points obtained from inventory shows that individual perceives himself/herself insufficient for problem-solving skills. There are three sub-dimensions in the inventory. Cronbach's Alpha reliability coefficient of 5th, 10th, 11th, 12th, 19th, 23rd, 24th, 27th, 33rd, 34th and 35th items constituting the subdimension of Reliance on Problem-Solving Skill (RPSA) is 0.85; Cronbach's Alpha reliability coefficient of 1st, 2nd, 4th, 6th, 7th, 8th, 13th, 15th, 16 th, 17th, 18th, 20th, 21st, 23rd, 30th and 31st items constituting the sub-dimension of "ApproachAvoidance (AA)" is 0.84; and Cronbach's Alpha reliability coefficient of 3, 14, 25, 26 and 32nd items constituting the sub-dimension of "Self-Control (SC)" is 0,72 . Cronbach's Alpha reliability coefficient of the inventory in total used in this study is 0.822 ; the coefficient of sub-dimension of reliance on problemsolving skill is 0.737 ; the coefficient of sub-dimension of approach-avoidance is 0,686 and the coefficient of sub-dimension of self-control was calculated as 0.643 .

\section{Statistical Analysis}

Shapiro Wilk and Levene tests were first applied to data obtained from the study in order to control normality hypothesis and homogeneity hypothesis of variables. Therefore, in accordance with the purposes of the study, one-way variance analysis (One-Way ANOVA) and Tukey HSD multiple comparison tests were used. For all statistical calculations, SPSS 21.0 statistical package was used, and results were accepted to be significant on the level of $(p<0.05)$.

\section{RESULTS}

As in Table 1 , it is confirmed that there is significant difference in the dimensions of "Total Point", "Reliance on Problem-Solving Skill" and "Approach-Avoidance" with respect to sporting age variable $(p<0.05)$. In the dimension of "Self-Control", any statistically significant difference is not available $(\mathrm{p}>0.05)$. 
Likewise, when Table 2 and Table 3 are examined, any significant difference were not statistically found in the sub-dimensions and total points in terms of "position" and "weekly training frequency" variables $(p>0.05)$.

Table 1. Problem-solving skill in terms of sporting age.

\begin{tabular}{|c|c|c|c|c|c|c|c|}
\hline Dimensions & Sporting Age & $\mathrm{N}$ & Mean & SD & Minimum & Maximum & $\mathrm{p}$ \\
\hline \multirow[t]{4}{*}{ Total Point } & $1-6$ & 40 & 96.08 a & 15.56 & 55.00 & 119.00 & $0.029^{*}$ \\
\hline & $7-13$ & 77 & 94.19 ab & 17.21 & 52.00 & 122.00 & \\
\hline & 14 and above & 27 & $85.26^{b}$ & 18.51 & 45.00 & 126.00 & \\
\hline & Total & 144 & 93.04 & 17.33 & 45.00 & 126.00 & \\
\hline \multirow[t]{4}{*}{ RPSA } & $1-6$ & 40 & 30.53 a & 7.79 & 12.00 & 47.00 & $0.051^{*}$ \\
\hline & $7-13$ & 77 & 29.70 ab & 7.71 & 14.00 & 46.00 & \\
\hline & 14 and above & 27 & $26.11^{b}$ & 6.70 & 11.00 & 38.00 & \\
\hline & Total & 144 & 29.26 & 7.66 & 11.00 & 47.00 & \\
\hline \multirow[t]{4}{*}{ AA } & $1-6$ & 40 & $51.25^{a}$ & 7.63 & 29.00 & 62.00 & $0.040^{*}$ \\
\hline & $7-13$ & 77 & 50.39 ab & 9.57 & 25.00 & 68.00 & \\
\hline & 14 and above & 27 & $45.63 \mathrm{~b}$ & 10.99 & 25.00 & 75.00 & \\
\hline & Total & 144 & 49.74 & 9.52 & 25.00 & 75.00 & \\
\hline \multirow[t]{4}{*}{ SC } & $1-6$ & 40 & 17.45 & 3.72 & 10.00 & 29.00 & 0.146 \\
\hline & $7-13$ & 77 & 17.39 & 4.15 & 6.00 & 28.00 & \\
\hline & 14 and above & 27 & 15.74 & 3.76 & 9.00 & 25.00 & \\
\hline & Total & 144 & 17.10 & 3.99 & 6.00 & 29.00 & \\
\hline
\end{tabular}

Table 2. Problem-solving skill with regard to positions.

\begin{tabular}{|c|c|c|c|c|c|c|c|}
\hline Dimensions & Position & $\mathrm{N}$ & Mean & SD & Minimum & Maximum & $\mathrm{p}$ \\
\hline \multirow[t]{4}{*}{ Total Point } & Forward & 34 & 94.38 & 19.71 & 45.00 & 122.00 & 0.368 \\
\hline & Midfield & 38 & 94.39 & 17.45 & 52.00 & 126.00 & \\
\hline & Defence & 59 & 90.24 & 16.69 & 53.00 & 119.00 & \\
\hline & Goalkeeper & 13 & 98.31 & 12.10 & 73.00 & 117.00 & \\
\hline \multirow[t]{4}{*}{ RPSA } & Forward & 34 & 30.21 & 7.96 & 11.00 & 43.00 & 0.311 \\
\hline & Midfield & 38 & 30.05 & 8.28 & 14.00 & 46.00 & \\
\hline & Defence & 59 & 27.83 & 7.31 & 12.00 & 47.00 & \\
\hline & Goalkeeper & 13 & 30.92 & 6.16 & 18.00 & 40.00 & \\
\hline \multirow[t]{4}{*}{$\mathrm{AA}$} & Forward & 34 & 49.76 & 10.40 & 25.00 & 68.00 & 0.449 \\
\hline & Midfield & 38 & 50.45 & 10.43 & 26.00 & 75.00 & \\
\hline & Defence & 59 & 48.54 & 8.91 & 25.00 & 67.00 & \\
\hline & Goalkeeper & 13 & 53.00 & 6.62 & 43.00 & 64.00 & \\
\hline \multirow[t]{4}{*}{ SC } & Forward & 34 & 17.88 & 3.99 & 10.00 & 29.00 & 0.217 \\
\hline & Midfield & 38 & 17.11 & 4.34 & 6.00 & 25.00 & \\
\hline & Defence & 59 & 16.37 & 3.96 & 7.00 & 28.00 & \\
\hline & Goalkeeper & 13 & 18.31 & 2.39 & 15.00 & 24.00 & \\
\hline
\end{tabular}


Table 3. Problem-solving skill with regard to weekly training frequency.

\begin{tabular}{|c|c|c|c|c|c|c|c|}
\hline Dimensions & Weekly Training Frequency & $\mathrm{N}$ & Mean & SD & Minimum & Maximum & $\mathrm{p}$ \\
\hline \multirow[t]{5}{*}{ Total Point } & 5 days & 23 & 93.52 & 19.84 & 55.00 & 121.00 & 0.863 \\
\hline & 4 days & 40 & 91.70 & 16.56 & 52.00 & 115.00 & \\
\hline & 3 days & 61 & 92.65 & 17.86 & 45.00 & 122.00 & \\
\hline & 2 days & 17 & 97.23 & 11.34 & 76.00 & 114.00 & \\
\hline & 1 day & 3 & 91.33 & 31.34 & 65.00 & 126.00 & \\
\hline \multirow[t]{5}{*}{ RPSA } & 5 days & 23 & 29.52 & 8.92 & 11.00 & 42.00 & 0.598 \\
\hline & 4 days & 40 & 28.42 & 7.90 & 12.00 & 46.00 & \\
\hline & 3 days & 61 & 29.72 & 7.36 & 16.00 & 47.00 & \\
\hline & 2 days & 17 & 30.23 & 6.86 & 17.00 & 43.00 & \\
\hline & 1 day & 3 & 23.33 & 3.78 & 19.00 & 26.00 & \\
\hline \multirow[t]{5}{*}{ AA } & 5 days & 23 & 50.86 & 9.68 & 29.00 & 67.00 & 0.449 \\
\hline & 4 days & 40 & 49.25 & 9.51 & 25.00 & 65.00 & \\
\hline & 3 days & 61 & 48.57 & 9.69 & 25.00 & 68.00 & \\
\hline & 2 days & 17 & 53.23 & 5.41 & 44.00 & 61.00 & \\
\hline & 1 day & 3 & 51.33 & 21.50 & 33.00 & 75.00 & \\
\hline \multirow[t]{5}{*}{ SC } & 5 days & 23 & 17.26 & 4.25 & 11.00 & 28.00 & 0.907 \\
\hline & 4 days & 40 & 16.82 & 4.16 & 6.00 & 24.00 & \\
\hline & 3 days & 61 & 17.31 & 3.99 & 9.00 & 29.00 & \\
\hline & 2 days & 17 & 16.52 & 3.10 & 12.00 & 23.00 & \\
\hline & 1 day & 3 & 18.33 & 5.85 & 14.00 & 25.00 & \\
\hline
\end{tabular}

Table 4. Problem-solving skill with respect to father's educational background.

\begin{tabular}{|c|c|c|c|c|c|c|c|}
\hline Dimensions & Father's Educational Background & $\mathrm{N}$ & Mean & SD & Minimum & Maximum & $\mathrm{p}$ \\
\hline \multirow[t]{4}{*}{ Total Point } & Literate & 10 & 92.90 ab & 18.43 & 65.00 & 119.00 & $0.031^{*}$ \\
\hline & Primary-Secondary School & 74 & $89.25^{b}$ & 17.15 & 45.00 & 117.00 & \\
\hline & High School & 38 & 99.26 a & 16.47 & 53.00 & 126.00 & \\
\hline & Higher Education and Above & 22 & 95.09 ab & 16.53 & 57.00 & 118.00 & \\
\hline \multirow[t]{4}{*}{ RPSA } & Literate & 10 & 28.30 ab & 8.21 & 16.00 & 44.00 & $0.025^{*}$ \\
\hline & Primary-Secondary School & 74 & $27.60^{b}$ & 7.62 & 12.00 & 46.00 & \\
\hline & High School & 38 & 32.07 a & 8.06 & 11.00 & 47.00 & \\
\hline & Higher Education and Above & 22 & 30.36 ab & 5.31 & 20.00 & 38.00 & \\
\hline \multirow[t]{4}{*}{ AA } & Literate & 10 & 50.50 & 9.67 & 35.00 & 60.00 & 0.088 \\
\hline & Primary-Secondary School & 74 & 48.00 & 9.37 & 25.00 & 67.00 & \\
\hline & High School & 38 & 52.81 & 8.91 & 25.00 & 75.00 & \\
\hline & Higher Education and Above & 22 & 49.90 & 10.17 & 25.00 & 62.00 & \\
\hline \multirow[t]{4}{*}{ SC } & Literate & 10 & 16.80 & 4.84 & 7.00 & 24.00 & 0.503 \\
\hline & Primary-Secondary School & 74 & 16.64 & 4.20 & 6.00 & 29.00 & \\
\hline & High School & 38 & 17.65 & 3.67 & 9.00 & 25.00 & \\
\hline & Higher Education and Above & 22 & 17.77 & 3.35 & 12.00 & 23.00 & \\
\hline
\end{tabular}


In the research, while there is significant difference in the dimension of "reliance on problemsolving skill" and the averages of "total point" with regard to father's educational background $(p<0.05)$, any differences aren't available for the dimensions of "approach-avoidance" and "self-control" ( $p>0.05)$.

Any significant difference was not statistically found in the averages of "total point" and subdimensions of "mother's educational background", variables of the research group $(\mathrm{p}>0.05)$.

According to the Table 6, with regard to the variable of income status of family, there is significant difference in the sub-dimensions "Total Point" and "Approach-Avoidance" $(\mathrm{p}<0.05)$. Any significant difference was not statistically found in the subdimensions "Reliance on Problem-Solving Skill" and "Self-Control" ( $p>0.05)$.

\section{DISCUSSION}

In this study which was conducted to determine the problem-solving skills of female futsal teams playing in the league of Turkish Universities Sports Federation with respect to some variables. "Reliance on Problem-Solving Skill", "Approach-Avoidance", "Self-Control" and "Total P Point" which are the subdimensions of problem-solving skill have been examined with respect to some variables, the gathered data have been discussed on the basis of literature. The low number of points gained from inventory has showed that participants' problemsolving skills are high, the reverse indicates that it is low.

It has been reported that there is significant relation between problem-solving skill and attendance in sportive activities in many studies which are in the literature Şah (22), Şenduran \& Amman (24), Kuru \& Karabulut, (19), Akandere et al. (2) Canan \& Ataoğlu (6), Acar et al. (1).

When the sporting age variable is analysed in the study, there is significant difference in the subdimensions of "TP", "RPSA", and "AA" of the participants. There is no significant difference found in the sub-dimension of "SC". According to this finding, it is clear that problem-solving skills of participants increase as their sporting age rises (Table 1). But Gülşen (10) could not find any significant difference in the sporting age in the study on football players. This situation doesn't match up with the obtained results. On the other hand, it can be said that this difference is due to the distinction between indoor and outdoor football games. Actually indoor football requires making faster decision and more consideration than others. It means that mental process is higher in this play.

Table 5. Problem-solving skill with respect to mother's educational background.

\begin{tabular}{|c|c|c|c|c|c|c|c|}
\hline Dimensions & Mother's Educational Background & $\mathrm{N}$ & Mean & SD & Minimum & Maximum & $\mathrm{p}$ \\
\hline \multirow[t]{4}{*}{ Total Point } & Literate & 22 & 90.00 & 16.80 & 53.00 & 119.00 & 0.201 \\
\hline & Primary Secondary School & 84 & 91.89 & 17.54 & 45.00 & 122.00 & \\
\hline & High School & 28 & 95.46 & 18.12 & 57.00 & 126.00 & \\
\hline & Higher Education and Above & 10 & 102.60 & 11.59 & 83.00 & 118.00 & \\
\hline \multirow[t]{4}{*}{ RPSA } & Literate & 22 & 28.27 & 7.73 & 17.00 & 44.00 & 0.371 \\
\hline & Primary-Secondary School & 84 & 28.76 & 7.87 & 11.00 & 47.00 & \\
\hline & High School & 28 & 30.32 & 7.53 & 16.00 & 43.00 & \\
\hline & Higher Education and Above & 10 & 32.60 & 5.56 & 21.00 & 40.00 & \\
\hline \multirow[t]{4}{*}{$\mathrm{AA}$} & Literate & 22 & 47.77 & 9.95 & 25.00 & 60.00 & 0.209 \\
\hline & Primary-Secondary School & 84 & 49.19 & 9.20 & 25.00 & 68.00 & \\
\hline & High School & 28 & 51.14 & $1 ., 80$ & 25.00 & 75.00 & \\
\hline & Higher Education and Above & 10 & 54.70 & 5.55 & 44.00 & 62.00 & \\
\hline \multirow[t]{4}{*}{ SC } & Literate & 22 & 16.18 & 3.04 & 10.00 & 24.00 & 0.544 \\
\hline & Primary-Secondary School & 84 & 17.11 & 4.39 & 6.00 & 29.00 & \\
\hline & High School & 28 & 17.32 & 3.58 & 7.00 & 25.00 & \\
\hline & Higher Education and Above & 10 & 18.30 & 3.26 & 12.00 & 23.00 & \\
\hline
\end{tabular}


Table 6. Problem-solving skill with regard to income status.

\begin{tabular}{|c|c|c|c|c|c|c|c|}
\hline Dimensions & Income Status (TL) & $\mathrm{N}$ & Mean & SD & Minimum & Maximum & $\mathrm{p}$ \\
\hline \multirow[t]{5}{*}{ Total Point } & $1000-1500$ & 44 & $85.98^{\mathrm{b}}$ & 17.49 & 45.00 & 119.00 & $0.011^{*}$ \\
\hline & $1501-2000$ & 35 & $97.43^{a}$ & 13.61 & 65.00 & 117.00 & \\
\hline & $2001-2500$ & 39 & $96.54^{\mathrm{ab}}$ & 16.08 & 53.00 & 121.00 & \\
\hline & $3001-3500$ & 14 & $97.71^{\mathrm{a}}$ & 19.79 & 52.00 & 126.00 & \\
\hline & 3501 and above & 12 & $89.33^{a b}$ & 20.83 & 57.00 & 118.00 & \\
\hline \multirow[t]{5}{*}{ RPSA } & $1000-1500$ & 44 & 26.84 & 7.11 & 11.00 & 44.00 & 0.084 \\
\hline & $1501-2000$ & 35 & 31.09 & 6.94 & 19.00 & 46.00 & \\
\hline & $2001-2500$ & 39 & 30.64 & 7.64 & 14.00 & 47.00 & \\
\hline & $3001-3500$ & 14 & 29.71 & 9.22 & 18.00 & 46.00 & \\
\hline & 3501 and above & 12 & 27.75 & 8.41 & 12.00 & 40.00 & \\
\hline \multirow[t]{5}{*}{ AA } & $1000-1500$ & 44 & $45.98^{\mathrm{b}}$ & 9.51 & 25.00 & 62.00 & $0.019^{*}$ \\
\hline & $1501-2000$ & 35 & $52.14^{a}$ & 7.69 & 30.00 & $64, .00$ & \\
\hline & $2001-2500$ & 39 & $51.13^{\mathrm{ab}}$ & 8.69 & 25.00 & 65.00 & \\
\hline & $3001-3500$ & 14 & $52.71^{\mathrm{a}}$ & 11.09 & 29.00 & 75.00 & \\
\hline & 3501 and above & 12 & $48.50^{\mathrm{ab}}$ & 11.88 & 25.00 & 67.00 & \\
\hline \multirow[t]{5}{*}{ SC } & $1000-1500$ & 44 & 16.11 & 4.13 & 7.00 & 29.00 & 0.234 \\
\hline & $1501-2000$ & 35 & 17.29 & 3.76 & 9.00 & 28.00 & \\
\hline & $2001-2500$ & 39 & 17.85 & 3.12 & 10.00 & 23.00 & \\
\hline & $3001-3500$ & 14 & 18.21 & 5.71 & 6.00 & 25.00 & \\
\hline & 3501 and above & 12 & 16.42 & 4.01 & 10.00 & 23.00 & \\
\hline
\end{tabular}

In the research study, when the problem-solving skill is analysed with respect to position during the game, which is another variable, there isn't any significant difference in the sub-dimensions of "TP", RPSA", "AA" and "SC" (Table 2). In the study of Gülşen (10), it is clear that the problem-solving skill of football players don't show any difference according to position of the players. But Gülşen (10) emphasizes that midfield players have higher level of problem-solving skills that other positions. In a study on basketball players who play in the away league, İnce and Şen (13) have reported that there isn't any statistically significant difference between positions and problem-solving skill. These findings are surprising. Because positions in futsal game aren't based on technic and tactics. These positions improve the mental process of the players, and also experienced players in these positions have different ways of thinking. On the other hand, there is not enough work on this situation. In this context, when the content and quality of this study is extended, it is thought that positions have important effect on problem-solving skill.
On the other hand, when the variable of weekly training frequency and problem-solving skill are evaluated together in the study, it has been found that there isn't any significant difference in the subdimensions of "TP", "RPSA", "AA" and "SC". Karabulut and Ulucan (14) has indicated in his study that sportive activities effect the problem-solving skill positively, and Karabulut and Ulucan (14) report that problem-solving skill of the children who stay in reformatory and doing sports actively has significant difference in the sub-dimensions " $\mathrm{AA}^{\prime}$ in comparison with the children who don't do any sports. In another study related to this topic conducted by Şenduran and Amman (24), it has been stated that students doing sports are likely to use problem-solving approach more frequently and effectively than the other athletes. When this information in literature are evaluated, it can be thought that the quality, process and purpose of sports may have differences in individual's problemsolving skills.

When the variables of "Father's educational background" and "Mother's educational 
background" are examined in the study, "Father's educational background" shows difference in only sub-dimensions of "TP" and "RPSA". There is no significant difference in "Mother's educational background" variable (Table 4-Table 5). In his study, Kirılmazkaya (17) compared social skills and problem-solving skills of teacher candidates of the departments Science Teaching and School Teaching; according to this research, while problem-solving skills don't differentiate with respect to "Mother's Educational Background", it has been determined the students whose father's educational level is primary school use "avoidant approach" more than the students whose father's educational level is higher education. Kenndy et al. (16) in their research reached the conclusion that the factors that affect the relations of teenagers within family and the criteria for academic success of them are effective on solving person-to-person cognitive and social problems. In a study by Gülşen (10) in which the relations between the learning styles of students and their problemsolving skills are analysed, any significance wasn't statistically found in the variables of parental educational background. Similarly, in another study by Korkut (18) in which problem-solving skills of high school students are examined, again there isn't any significant difference found in the variables of parental educational background. Based on all these research findings, it is non-negligible that parents are important factor in their children's problem-solving skills. Individuals often need parental help in order to solve complicated problems.

Within this scope, educational level of the parents who will provide help has an important effect in solving problems. Results are such as to support aforementioned situation.

As a matter of fact, it has been found that father's educational level has an important effect in problemsolving. But the same situation is out of question for mother's educational level; this situation can be said to result from

When the variable of "Income Status" that is thought to have an important effect on individuals' problem-solving skills, significance has been found in the sub-dimensions of "TP" and "AA" (Table 6). These results show that problem-solving skills grow positively as the income level of individual increases. But the sub-dimensions of "RPSA" and "SC" don't show such development. This situation can be associated with their attitude towards material things during individual's development of psycho-social behavioural process. In a study related to this subject by Akbaş (3), he examined social problem-solving skills of 6-years-old children who attend pre-school education, and found that problem-solving skills of the participants increases as the socio-economic level of them increases. In another study by Terzi (26), interpersonal sense of problem of the $6^{\text {th }}$ grade students in the second level of primary education was studied; as a result, it has been found that their perception towards inter-personal problem-solving skills indicate significant differences with regard to their parent's attitude and socio-economic level. Regarding to all these findings, it can be said that socio-economic status plays an important role in every stage of an individual's development. In numerous studies, it is emphasized that children of the families of middle and upper-class attend social activities more frequently, and that these activities play an important role in their development. Therefore, economical factor is largely remarkable for an individual's problem-solving skill.

As a consequence, it is evident that level of problem-solving skills of individuals rises as the sporting age increases. In fact, it can be said that futsal game develops individual's problem-solving, quick deciding and reasoning skills. Therefore, it can be said that this type of sport that is adopted at early ages has a positive effect on individual's problemsolving skills. Also, it can be claimed that social environment that surrounds individuals has different effects on their problem-solving skills.

\section{REFERENCES}

1. Acar K, Akandere M, Bastug G. A study of problem solving skills and non-functional attitudes of children who get training for football. Turkish Journal of Sport and Exercise, 2013; 15(3): 69-74.

2. Akandere $M$, Baştuğ $G$, Demir $H$, Taşğın Ö. Examining problem solving skills of the students practising dance for 12 weeks in terms of gender variable. Ovidius University Annals, Series Physical Education and Sport Science, Movement and Healty, 2010;2: 635-638.

3. Akbaş C. Okul öncesi eğitime devam eden altı yaş grubu çocukların sosyal problem çözme becerilerinin incelenmesi. Ankara, Yüksek Lisans Tezi, Hacettepe Üniversitesi, 2005.

4. Aksu M. Felsefe ve Sosyal Bilimler Kongresi, Bildiriler 1, Erzurum, 1984.

5. Aldemir GY, Biçer T, Kale EK. Effect of imagination analysis of football players on problem-solving. Journal of Sports and Performance, 2014; 5(2): 37-45.

6. Canan F, Ataoğlu A. Anksiyete, depresyon ve problem çözme becerisi algısı üzerine düzenli sporun etkisi. Anadolu Psikiatri Dergisi, 2010; 11(1): 38-43.

7. Costa IJ, Garganta P, GrecoI Mesquita B, Silva E, Müller D, Castelã A, Rebelo S. Analysis of tactical behaviours in smallsided soccer games: Comparati ve study between goal posts of 
society soccer and futsal. The Open Sports Sciences Journal, $2010 ; 3: 10-12$.

8. Cüceloğlu D. İnsan ve Davranış, Remzi Kitapevi, İstanbul, 2004.

9. D'Zurilla TJ, Nezu AM. Problem Solving Therapies. Handbook of Cognitive Behavioural Therapies, 2nd ed. Editor: Dobson KS. Guilford Pres, New York, 2001.

10. Gülşen D. Farklı lig düzeyinde oynayan futbolcuların oynadıkları mevkilere, öğrenim durumu ve spor yaşlarına göre problem çözme becerilerinin incelenmesi. Adana, Yüksek Lisans Tezi, Çukurova Üniversitesi, 2008.

11. Güzel A. Marmara üniversitesi öğrencilerinin öğrenme stilleri ile problem çözme becerileri arasındaki ilişkinin incelenmesi. İstanbul, Yayınlanmış Yüksek Lisans Tezi, Marmara Üniversitesi Eğitim Bilimleri Enstitüsü, 2004.

12. Heppner PP, Petersen CH. The development and implications of a personal problem solving inventory. Journal of Counseling Psychology, 1982; 29: 66-79.

13. Ince $G$, Şen C. Adana ilinde deplasmanli ligde basketbol oynayan sporcularin problem çözme becerilerinin belirlenmesi. Spormetre Beden Eğit ve Spor Bil Derg, 2006; 4(1): 5-10.

14. Karabulut EO, Ulucan H. Yetiştirme yurdunda kalan öğrencilerin problem çözme becerilerinin çeşitli değişkenler bakımından incelenmesi (Kırşehir ili örneği). Ahi Evran Üniversitesi Eğitim Fakültesi Dergisi, 2011; 12(1); 277-238.

15. Karasar N. Bilimsel Araştırma Yöntemi, Nobel Yayın Dağıtım, 17.Bask1, Ankara, 2008.

16. Kenndy MG, Fenler FD, Cauce A, Primevera J. Social problem solving in adjustment in adolescence. The influence of moral reasoning level. Scoring alternatives and family climate. Journal of Clinical Child Psychology, 1998; 17(1); 73-83.

17. Kırılmazkaya G. İlköğretim fen bilgisi ve sınıf öğretmen adaylarının problem çözme becerileri ve sosyal becerilerinin karşılaştırılması. Elazı ̆̆, Yayınlanmış Yüksek Lisans Tezi, Fırat Üniversitesi Fen Bilimleri Enstitüsü, 2010.

18. Korkut F. Lise öğrencilerinin problem çözme becerileri. Hacettepe Üniversitesi Eğitim Fakültesi Dergisi, 2002; 22: 177 184.

19. Kuru E, Karabulut EO. Ritim eğitimi ve dans dersi alan ve almayan beden eğitimi ve spor yüksekokulu öğrencilerinin problem çözme becerilerinin çeşitli değişkenler bakımından incelenmesi. Gazi Üniversitesi Gazi Eğitim Fakültesi Dergisi, 2009; 29(2); 441-458.

20. Senemoğlu N. Gelişim, Öğrenme ve Öğretim, Ertem Matbaacilık, Ankara, 1997.

21. Sevim Y. Antrenman Bilgisi, Nobel Yayın Dağıtım, Ankara, 2002

22. Şah H. Spor yapan ve yapmayan bedensel engellilerin problem çözme becerileri arasındaki farklılıkların incelenmesi. Yayınlanmamış Yüksek Lisans Tezi, Mersin Üniversitesi Sağlık Bilimleri Enstitüsü, Mersin, 2005.

23. Savaşır İ Şahin NH. Assessment in Cognitive Behavioural Therapies: Frequently Used Scales. Ankara. Association of Turkish Psychologists Publications, 1997.

24. Şenduran F, Sporcu olan ve olmayan ortaöğretim öğrencilerinin problem çözme yaklaşımları, 9. Uluslararası Spor Bilimleri Kongresi, 3-5 Kasım. Muğla Üniversitesi Atatürk Kültür Merkezi, Muğla, 2006.

25. Taylan S. Heppner'in problem çözme envanteri'nin uyarlama, geçerlik ve güvenirlik çalışmaları. Yüksek Lisans Tezi, Ankara Üniversitesi, Sosyal Bilimler Enstitüsü, Ankara, 1990.

26. Terzi Ş. Altıncı sınıf öğrencilerinin kişiler arası problem çözme beceri algıları. Türk Eğitim Bilimleri, 2003; 1(2): 221-232.

27. Vilar L, Araujo D, Davids K, Travasso B. Constraints on competitive performance of attacker-defender dyads in team sports, Journal of Sports Sciences, 2001; 30(5): 459-469. 